\title{
Quaternary Ammonium Compounds as New Sanitizers for Reducing the Spread of the Olive Knot Pathogen on Orchard Equipment
}

\author{
K. A. Nguyen, H. Förster, and J. E. Adaskaveg, Department of Plant Pathology and Microbiology, University of California, Riverside, \\ 92521
}

\begin{abstract}
Olive knot, caused by the wound pathogen Pseudomonas savastanoi pv. savastanoi, is a serious bacterial disease that can be disseminated by orchard equipment. Greenhouse studies confirmed that cutting tools contaminated during contact with olive knots are able to spread the pathogen to healthy olive tissue. Quaternary ammonium compounds (QACs) were assessed as sanitizing agents for contaminated equipment as a disease management strategy. In laboratory in vitro tests, QACs exhibited high toxicity against the bacterium over a broad $\mathrm{pH}$ range from 6 to 9 using short exposure periods ( 15 to $60 \mathrm{~s}$ ) and low concentrations $(5 \mu \mathrm{g} / \mathrm{ml})$. QACs applied to contaminated hard surfaces in the presence of an organic load reduced bacterial recovery by $\geq 3.6 \log _{10} \mathrm{CFU} / \mathrm{ml}$. In field trials, sanitation of hedging

equipment that was contaminated with the pathogen $\left(2 \times 10^{7} \mathrm{CFU} / \mathrm{ml}\right)$ and used to prune olives, was successful and sometimes completely prevented new infections from occurring. Application of additional foliar spray treatments of copper or copper-kasugamycin mixtures after hedging significantly improved disease control. In laboratory and field studies, sodium hypochlorite was significantly less effective than QAC compounds in the presence of organic matter. A nonphenolic QAC formulation, however, was ineffective as a preventative treatment when applied prior to inoculation of olive wounds, whereas a copper hydroxide application was highly effective. Based on data from this research, a QAC formulation was registered for field use as a sanitizer for olive equipment in California in 2015.
\end{abstract}

Olive knot, caused by the bacterium Pseudomonas savastanoi pv. savastanoi (Gardan et al. 1992), is a disease that has afflicted olive trees (Olea europaea L.) since ancient times (Iacobellis 2001) and was likely introduced to California during the early 19th century (Bioletti 1898). The disease is of economic importance because infections result in a decline in tree health, reduced yield, and potentially decreased olive oil quality (Schroth et al. 1963, 1973; Young 2004). Orchards with severe disease are often removed entirely. $P$. savastanoi pv. savastanoi is a wound-infecting pathogen that incites the development of knots or galls after invading plant injuries (Ramos et al. 2012; Wilson 1935). Knots serve as the primary inoculum source, releasing copious amounts of bacteria when wetted. Rainfall promotes the dissemination of the bacterium (Horne et al. 1912), but new olive production practices provide an additional dissemination mechanism in the absence of rain. These new methods consist of high-density plantings of olives in hedgerows that are mechanically pruned and harvested (Ferguson et al. 2010; Vossen 2007). Field equipment coming in contact with infected tissues (knots) often become contaminated with $P$. savastanoi pv. savastanoi (Wilson 1935). The equipment can subsequently spread the pathogen to healthy trees as it continues down the hedgerow while also creating injuries necessary for infection (Tous et al. 2010). The disease can spread rapidly in an orchard from a single infected tree using these types of cultivation practices. Over time, build-up of inoculum will contribute to a decline in orchard health and productivity (Quesada et al. 2010a; Schroth et al. 1973).

Growing consumer demands for olive-based food products with their benefits on human health have led to an increase in production. With the rising cost of labor, growers are relying more on mechanized practices to provide an adequate supply of olives while remaining profitable (Tous et al. 2010; Vossen 2007). Eradication of olive knot is nearly impossible once the disease becomes established in an orchard. Management strategies include removal of infected branches by pruning and the use of foliar sprays with copper-based compounds after pruning and harvesting (Quesada et al. 2010b; Teviotdale and Krueger 2004). Copper is a protective treatment that

Corresponding author: J. E. Adaskaveg; E-mail: jim.adaskaveg@ucr.edu

Accepted for publication 8 February 2017.

() 2017 The American Phytopathological Society is most effective when applied to plants before infection by the pathogen. Other chemical control options include the manual application of cresol- and xylenol-based compounds (e.g., Gallex) to knots, but this is not feasible on a commercial scale (Schroth and Hildebrand 1968; Sibbett and Ferguson 2005). The lack of olive cultivars that show resistance to the disease contributes to the problem (Penyalver et al. 2006). Therefore, new management strategies are necessary.

One way to reduce the spread of olive knot could be to routinely sanitize field equipment during usage, and this was evaluated in our research. Among sanitizers that are currently available for commercial use, sodium hypochlorite can be highly effective, but is corrosive to equipment. Quaternary ammonium compounds (QACs) were developed in the 1930s and have been widely used as sanitizers to disinfect food and nonfood contact surfaces (Rahn and Van Eseltine 1947). They have been successfully employed in domestic, agricultural, and industrial applications, as well as in healthcare. QACs are cationic surfactants that are highly toxic against fungi, bacteria, and viruses. The mode of action of QACs against bacteria involves the disruption of the cell membrane through the interaction of the positively charged QAC with the phospholipid bilayer leading to cell leakage and death (Gilbert and Moore 2005). QACs have many beneficial properties that include being colorless, odorless, noncorrosive to metal surfaces, and they are temperature-stable. These compounds are effective in hard water and in the presence of organic matter, and have low mammalian toxicity (Walker and LaGrange 1991). QACs are currently registered as field equipment sanitizers in Florida to prevent the spread of the citrus canker pathogen Xanthomonas citri subsp. citri (Schubert and Sun 2003) and were shown to be effective in decontaminating some citrus plant surfaces (Bock et al. 2011). These attributes make QACs excellent candidates for use as disinfectants of field equipment to control olive knot. Therefore, the objectives of this study were to evaluate: i) the toxicity of QACs to $P$. savastanoi pv. savastanoi in vitro as compared with other sanitizers including sodium hypochlorite; ii) the effectiveness of QACs and sodium hypochlorite for sanitizing selected equipment surfaces in lab and field trials; and iii) the performance of a QAC formulation as a field treatment for disease prevention.

\section{Materials and Methods}

Culturing of $\boldsymbol{P}$. savastanoi pv. savastanoi and olive plants in the greenhouse. $P$. savastanoi pv. savastanoi strain $01-26$, originally isolated from an olive knot in California and positively identified by PCR using primers IAALF and IAALR (Penyalver et al. 2000), was 
used in all studies. Bacterial stocks were stored in $15 \%$ glycerol at $-80^{\circ} \mathrm{C}$ and cultured at $25^{\circ} \mathrm{C}$ on King's medium B agar (KMB; King et al. 1954) for 2 days before each study. 'Arbequina' and 'Manzanillo' olives (Agromillora California, Gridley, CA) were grown in sterilized soil in 3.78-liter plastic pots under greenhouse conditions at 15 to $30^{\circ} \mathrm{C}$. In field trials, the same olive cultivars were grown in a high-density planting system (Vossen 2007) to replicate commercial production at the University of California, Riverside and Davis field stations.

Spread of $P$. savastanoi pv. savastanoi from contaminated equipment to healthy olive tissues in greenhouse pruning studies. In order to determine if tools (e.g., scalpels) that were contaminated from cutting diseased tissue (i.e., olive knots) could transmit $P$. savastanoi pv. savastanoi to healthy tissue, twigs of 2- to 3-year-old 'Arbequina' olives were inoculated 1 year in advance to produce the required knots. Knot development was initiated by removing a small section of bark (approximately 2 to $3 \mathrm{~mm} \times 5$ to $8 \mathrm{~mm}$ ) with a scalpel, exposing a portion of cambial tissue. P. savastanoi pv. savastanoi inoculum was prepared by suspending 2-day-old cultures in sterile water and adjusted turbidimetrically $\left(\mathrm{OD}_{600 \mathrm{~nm}}=70 \%\right.$ light transmittance) to obtain $2 \times 10^{8}$ $\mathrm{CFU} / \mathrm{ml}$. This bacterial suspension was diluted with sterile distilled water to a final inoculum concentration of $10^{7} \mathrm{CFU} / \mathrm{ml}$ and sprayed onto wounded olive twigs using a hand-held sprayer. For pathogen transmission studies, a sterile scalpel was contaminated by making a cut through an olive knot (5 to $10 \mathrm{~mm}$ in diameter) with a single pass. Subsequently, the scalpel was used to make a small notched cut into twigs ( 1 to 2 years of age) of healthy 3- to 4-year-old 'Arbequina' or 'Manzanillo' olive plants, removing a 5-mm long piece of bark to a depth where cambial tissue was exposed (Fig. 1A). Between each contamination-inoculation sequence, the blade was sterilized with $70 \%$ ethanol. This process was repeated 10 times on each twig, and one twig of each of three plants was used (a total of 30 contaminationinoculation events). In similar tests, scalpel blades were either moistened with water before cutting into a knot followed by wounding a healthy twig; or knots were moistened with water, cut with a dry blade, and then the blade was used to wound a healthy twig. Positive controls were made by dipping a scalpel into a $P$. savastanoi pv. savastanoi suspension $\left(10^{8}\right.$ $\mathrm{CFU} / \mathrm{ml}$ ) before wounding a healthy twig, and negative controls were made by wounding healthy olive twigs with a sterile scalpel. Plants were evaluated for knot development after 3 months. These studies were performed twice.

Direct toxicity of selected sanitizing agents against $\boldsymbol{P}$. savastanoi pv. savastanoi. Sanitizers evaluated included QAC-1 containing a mixture of 5\% n-alkyl dimethyl benzyl ammonium chlorides and
5\% N-alkyl dimethyl ethylbenzyl ammonium chlorides (Deccosan 315; Decco US Post-Harvest, Inc., Monrovia, CA); QAC-2 containing a mixture of $6.51 \%$ alkyl dimethylbenzyl ammonium chloride, $3.255 \%$ didecyl dimethyl ammonium chloride, $3.255 \%$ octyl decyl dimethyl ammonium chloride, and $8.68 \%$ dioctyl dimethyl ammonium chloride (Deccosan 321; Decco US Post-Harvest); polyhexamethylene biguanide hydrochloride (PHMB; Vantocil IB; Arch Chemicals, Inc., Atlanta, GA); and chlorhexidine acetate (Nolvasan; Fort Dodge Animal Health, Fort Dodge, IA). These were compared with sodium hypochlorite (household bleach containing 5.25\% sodium hypochlorite). Solutions of sanitizing agents (10 $\mu \mathrm{g}$ total active ingredients/ ml) were mixed 1:1 with a $P$. savastanoi pv. savastanoi suspension $\left(2 \times 10^{8} \mathrm{CFU} / \mathrm{ml}\right)$ to obtain a final concentration of the sanitizing agents of $5 \mu \mathrm{g} / \mathrm{ml}$ in a total volume of $500 \mu$ l. Mixtures were gently vortexed and incubated for $60 \mathrm{~s}$. Immediately following exposure, a 1:1,000 dilution was made with sterile distilled water to stop the biocidal activity of the sanitizing agents, and the dilution was plated onto 10-cm KMB agar plates using a spiral plater (Autoplate 4000, Spiral Biotech, Inc., Norwood, MA). To confirm that diluted sanitizer solutions no longer had activity against $P$. savastano $i$ pv. savastanoi, bacterial suspensions were incubated in sanitizer solutions at final concentrations of $5 \mathrm{ng} / \mathrm{ml}$ for $30 \mathrm{~min}$ before plating. Plates were evaluated for bacterial growth after 3 to 4 days at $25^{\circ} \mathrm{C}$, and colonies were enumerated. Sanitizer efficacy was determined as the $\log _{10}$ reduction in $\mathrm{CFU} / \mathrm{ml}$ of the sanitizer treatment as compared with the water control.

In another test, bacterial survival was determined after selected exposure durations to QAC-2. For this, mixtures of QAC-2 and $P$. savastanoi pv. savastanoi were prepared as described above with a final QAC-2 concentration of $5 \mu \mathrm{g} / \mathrm{ml}$. Mixtures were lightly vortexed, incubated for $15,30,45$, or $60 \mathrm{~s}$, and plated as described previously. The toxicity of QAC-2 was also tested at selected $\mathrm{pH}$ conditions. A citric acid buffer was prepared containing $1.3 \mathrm{~g}$ anhydrous citric acid, $1.9 \mathrm{~g}$ glycine, and $1.9 \mathrm{~g}$ monobasic potassium phosphate in $50 \mathrm{ml}$ of distilled water (Lucas 1955). A mixture of $1.9 \mathrm{ml}$ sterilized buffer and $18.9 \mathrm{ml}$ of sterile distilled water was adjusted to $\mathrm{pH} 5,6,7,8$, or $9 \pm 0.1$ with $1 \mathrm{~N} \mathrm{NaOH}$. Suspensions of $P$. savastanoi pv. savastanoi and solutions of QAC-2 $(25 \mu \mathrm{g} / \mathrm{ml})$ were prepared in each of the buffer solutions and mixed using components of the same $\mathrm{pH}$. For the controls, P. savastanoi pv. savastanoi suspensions were mixed with the respective buffer solutions without QAC. After $60 \mathrm{~s}$ of incubation, suspensions were diluted 1:1,000 with sterile distilled water, and viable $P$. savastanoi pv. savastanoi

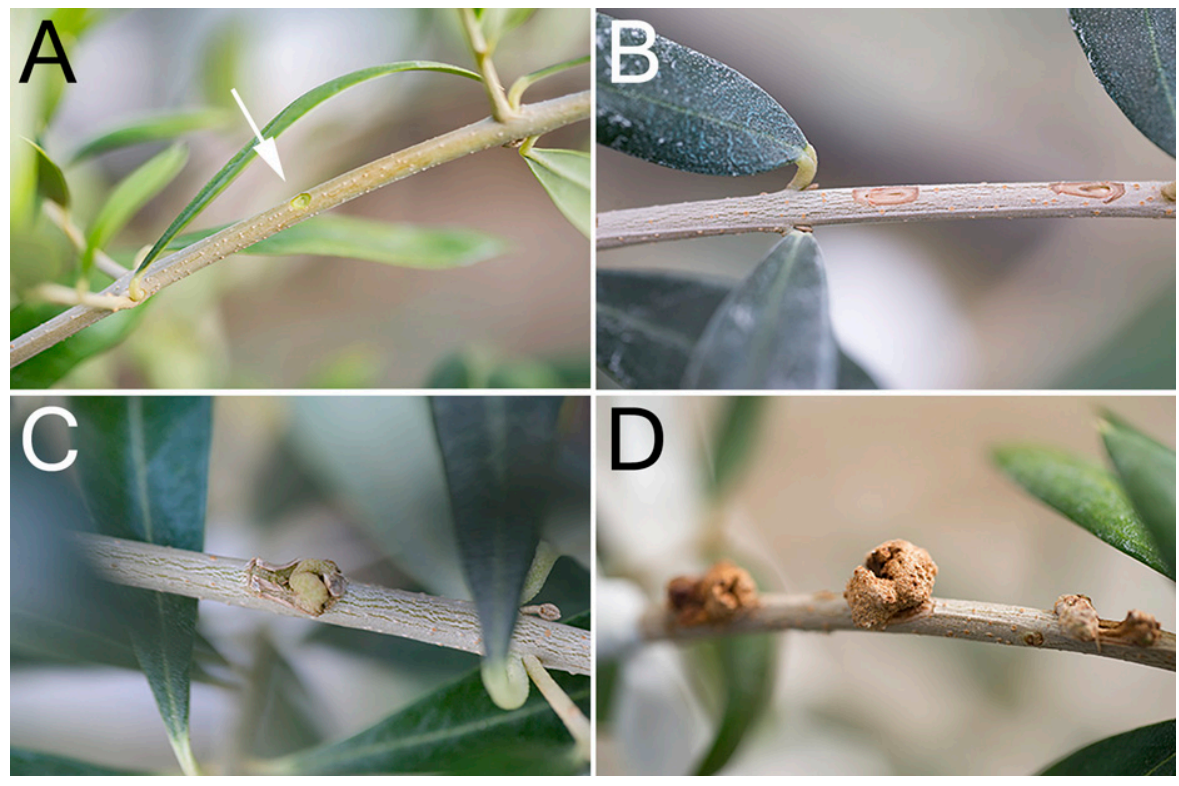

Fig. 1. 'Arbequina' olive twig injury and subsequent knot development in a greenhouse study. A, notched wound made with a scalpel on an olive twig (arrow). B, Noninoculated, healed wounds after 2 months. C, Knot that developed on an inoculated wound. D, Knots that developed 6 months after inoculation. 
cells were enumerated by plating as described above. For each treatment, there was a minimum of three replicates, and the experiments were done twice except for the exposure duration study that was performed three times. Sanitizer efficacy was determined as the $\log _{10}$ reduction in CFU/ $\mathrm{ml}$ by the sanitizer treatment as compared with the untreated control.

Efficacy of two QAC formulations and sodium hypochlorite in disinfecting hard surfaces contaminated with $\boldsymbol{P}$. savastanoi pv. savastanoi in macerated olive tissue. Young, succulent, greenhouse-grown 'Arbequina' olive twigs $(50 \mathrm{~g})$ were macerated in $250 \mathrm{ml}$ distilled water using a Waring blender for $60 \mathrm{~s}$. The macerate was strained through a $0.34-\mathrm{mm}$ mesh screen, and $50 \mathrm{~g}$ of solids were collected in a glass beaker. A bacterial suspension $(25 \mathrm{ml})$ containing $2 \times 10^{8} \mathrm{CFU} / \mathrm{ml}$ was added to the solids, and mixed thoroughly. Sterilized segments of polyvinyl chloride $(\mathrm{PVC})$ piping $(1.2 \mathrm{~cm}$ in diameter, $1 \mathrm{~cm}$ long) were added to the macerated tissue-bacteria mixture and stirred with a metal spatula until the PVC segments were well coated with macerated tissue. They were then placed onto a metal screen and sprayed with an aqueous solution of QAC-1, QAC-2 (both at 2,000 $\mu \mathrm{g} / \mathrm{ml}$ ), sodium hypochlorite $(100 \mu \mathrm{g} / \mathrm{ml}$ ), or water (control) using an atomizer (DeVilbiss 15-RD, Sunrise Medical, Inc., Somerset, PA) until runoff. After 90 s, each PVC segment was placed into a $50-\mathrm{ml}$ plastic tube containing $5 \mathrm{ml}$ of sterile distilled water and vortexed for $10 \mathrm{~s}$. The suspension was then spiralplated onto KMB as described for the direct toxicity assays.

Performance of QAC-2 as a sanitizer for pruning equipment contaminated with $P$. savastanoi pv. savastanoi in field studies. For spring and fall trials, the hedging teeth of a handheld gaspowered hedger (Model HL 40, Stihl, Inc., Virginia Beach, VA) were thoroughly sprayed with a suspension of $P$. savastanoi pv. savastanoi $\left(1 \times 10^{7} \mathrm{CFU} / \mathrm{ml}\right)$ and then with QAC-2 $(2,000 \mu \mathrm{g} / \mathrm{ml})$ or sodium hypochlorite $(50 \mu \mathrm{g} / \mathrm{ml})$ to runoff using a hand-held sprayer. After $90 \mathrm{~s}$, 3- to 4-year-old 'Arbequina' or 'Manzanillo' olive trees were pruned to create lateral cuts on larger limbs and terminal stub cuts of smaller branches. Pruning of olive branches with a noninoculated hedger was used as a negative control and pruning with a contaminated nonsanitized hedger as a positive control. In some cases, trees wounded with a QAC-2-sanitized hedger received additional applications of foliar spray treatments 1 to $2 \mathrm{~h}$ after hedging using an airblast sprayer (Model 420, Stihl). These treatments included copper hydroxide (Kocide 3000; Du Pont de Nemours and Co., Wilmington, DE) at $4,200 \mu \mathrm{g} / \mathrm{ml}(1,260 \mu \mathrm{g} / \mathrm{ml}$ metallic copper equivalent) or copper hydroxide 4,200 $\mu \mathrm{g} / \mathrm{ml}$ mixed with kasugamycin $100 \mu \mathrm{g} / \mathrm{ml}$ (Kasumin 2L; Arysta LifeScience, Cary, NC). The trials were done using a randomized complete block design (RCBD) with four single-tree replications per treatment. Trials were performed twice for each olive cultivar.

Table 1. Transmission of Pseudomonas savastanoi pv. savastanoi by contaminated cutting tools to healthy 'Manzanillo' or 'Arbequina' olive plants in greenhouse trials

\begin{tabular}{lcc}
\hline & $\begin{array}{c}\text { Incidence of knot formation on } \\
\text { twig wounds (\%) }\end{array}$ \\
\cline { 2 - 3 } & $\begin{array}{c}\mathbf{z} \\
\text { 'Manzanillo' } \\
\text { olive }\end{array}$ & $\begin{array}{c}\text { 'Arbequina' } \\
\text { olive }\end{array}$ \\
\hline Contamination-inoculation method & $96.7 \mathrm{a}$ & $100 \mathrm{a}$ \\
\hline $\begin{array}{c}\text { Scalpel contaminated with bacterial } \\
\text { suspension }\end{array}$ & $55.0 \mathrm{~b}$ & $23.3 \mathrm{~b}$ \\
$\begin{array}{c}\text { Scalpel single pass cut through wetted } \\
\text { knot }\end{array}$ & $58.3 \mathrm{~b}$ & $28.3 \mathrm{~b}$ \\
$\begin{array}{c}\text { Wetted scalpel single pass cut through } \\
\text { nonwetted knot }\end{array}$ & $20.0 \mathrm{c}$ & $5 \mathrm{bc}$ \\
$\begin{array}{c}\text { Scalpel single pass cut through } \\
\text { nonwetted knot }\end{array}$ & $0.0 \mathrm{~d}$ & $0 \mathrm{c}$ \\
\begin{tabular}{l} 
Sterile scalpel \\
\hline
\end{tabular}
\end{tabular}

y For each method, a sterile scalpel was treated as indicated and subsequently used to make a notched cut into a healthy olive twig. Contamination with $P$. savastanoi pv. savastanoi was done using a suspension of $10^{8} \mathrm{CFU} / \mathrm{ml}$.

${ }^{\mathrm{z}}$ Incidence of disease was recorded after 2 months and is based on the number of knots that formed of the total number of wounds made with each contamination-inoculation method. Data were analyzed using general linear model (GLM) and Fisher's LSD tests $(P \leq 0.05)$. Mean values followed by same letters are not significantly different for each cultivar.
Efficacy of QAC-3 as a preinfection, protective treatment for olive injuries in field studies. One- to two-year old twigs (5 to $15 \mathrm{~mm}$ in diameter) of 3- to 4-year old 'Manzanillo' or 'Arbequina' trees were wounded with two types of injuries: lateral wounds to replicate mechanical damage sustained from field equipment, and leaf scar wounds to simulate wounds formed after natural leaf drop. Lateral wounds were produced using a scalpel to cut parallel to the length of a twig so that cambial tissue 10 to $20 \mathrm{~mm}$ long and several $\mathrm{mm}$ wide was removed. For leaf scars, olive leaves were pulled off by hand. Each twig represented one replicate with five lateral wounds near the base of the twig (one wound between each internode) followed by five leaf scar wounds at consecutive internodes. QAC-3 (7.5\% didecyl dimethyl ammonium chloride; KleenGrow; Pace 49, Inc., Delta, B.C., Canada), which is labeled for ornamental crops as a pesticide to be applied directly to plant tissue or as an equipment sanitizer, was evaluated. The sanitizer solution was prepared at the maximum labeled rate by mixing $11.2 \mathrm{ml}$ of QAC-3 in 3.78 liters of water $(222 \mu \mathrm{g}$ active ingredient $/ \mathrm{ml})$, applied with a handheld sprayer on freshly made olive twig wounds until runoff, and allowed to dry. P. savastanoi pv. savastanoi $\left(1 \times 10^{8}\right.$ $\mathrm{CFU} / \mathrm{ml}$ ) was sprayed onto wounds to run-off. Positive controls included twigs that were wounded, inoculated, and treated with water. A treatment of copper hydroxide $(4,200 \mu \mathrm{g} / \mathrm{ml})$ was included as a negative control. Six to eight replicates were used per trial, and the study was done three times using a RCBD.

Statistical analysis of data. Data were analyzed using SAS software (version 9.4, SAS Institute, Inc., Cary, NC). For direct contact and hard surface disinfectant assays, recovery or reduction of bacteria was expressed as $\log _{10} \mathrm{CFU} / \mathrm{ml}$ and was analyzed using an analysis of variance (ANOVA). Treatment means were separated using Fisher's least significant difference (LSD) test. For direct contact assays, the loss of biocidal activity of each sanitizer after a 1:1,000 dilution (done to neutralize the sanitizer before plating) as compared with the water control was verified using ANOVA and LSD tests. For field and greenhouse tests, percent incidence of disease and percent reduction in disease incidence values were arcsine transformed before performing general linear model (GLM), and LSD analyses.

\section{Results}

Spread of $P$. savastanoi pv. savastanoi from contaminated equipment to healthy olive tissues in greenhouse pruning studies. Transmission of $P$. savastanoi pv. savastanoi and knot formation occurred when a scalpel was used to make an initial cut into an olive knot followed by a cut into a healthy olive twig (Fig. 1A, C, D). Overall, disease incidence was lower on 'Arbequina' as compared with 'Manzanillo' olives, but knots developed under all conditions evaluated except for the negative control (Fig. 1B). Water applied to a knot or scalpel before making the initial contamination cut significantly $(P<0.0001)$ increased the incidence of knot formation on previously healthy twigs of 'Arbequina' and 'Manzanillo' olives (Table 1).

Direct toxicity of selected sanitizing agents against $P$. savastanoi pv. savastanoi. There was no significant difference $(P=0.4333)$ in the number of colonies recovered when $P$. savastanoi pv. savastano $i$ was incubated in water or in solutions of QAC-1, QAC-2, chlorhexidine, or PHMB that were diluted 1:1,000 with sterile water (i.e., a final concentration of $5 \mathrm{ng}$ sanitizer/ml). Thus, this dilution of the solutions after incubation in the assay was adequate to neutralize their activity before viability of $P$. savastanoi pv. savastanoi was assessed. For sodium hypochlorite, however, the 1:1,000 dilution did not completely quench the biocidal activity. This dilution was still effective and significantly $(P<0.0001)$ lowered the bacterial populations from the control in contrast to the other diluted sanitizers.

The mean number of bacteria recovered for untreated controls was $1.3 \times 10^{5} \mathrm{CFU} / \mathrm{ml}$ (i.e., $5.1 \log _{10}$ ). QAC-1, QAC-2, chlorhexidine, and PHMB were all highly effective for inactivating $P$. savastanoi pv. savastanoi using concentrations of $5 \mu \mathrm{g} / \mathrm{ml}$ and 60 -s exposures. There was no significant difference $(P=0.6018)$ in activity among the sanitizers, and the number of colonies was significantly $(P<$ 0.0001 ) reduced from the water control by $3.2,3.3,3.6$, and $3.8 \log _{10}$ for QAC-1, QAC-2, chlorhexidine, and PHMB, respectively. Sodium hypochlorite at $5 \mu \mathrm{g} / \mathrm{ml}$ completely inhibited bacterial growth after 
$60 \mathrm{~s}$ of exposure and was significantly more effective than the other four sanitizer treatments $(P<0.0001)$.

A range of treatment exposure times was evaluated for QAC-2 at $5 \mu \mathrm{g} / \mathrm{ml}$, and there were no significant differences $(P=0.2811)$ for 15-, 30-, 45-, or 60-s durations (Fig. 2). Numerically, the 15-s exposure reduced the number of $P$. savastanoi pv. savastanoi colonies by $2.3 \log _{10}$ as compared with a $3.3-\log _{10}$ reduction after a 60 -s exposure. In evaluating the effect of $\mathrm{pH}$ on QAC-2 efficacy, QAC-2 in a solution of $\mathrm{pH} 5$ was significantly $(P=0.0018)$ less effective with a mean reduction in colonies of $0.5 \log _{10}$ as compared with $\mathrm{pH}$ values of $6,7,8$, or 9 . These latter solutions resulted in mean log reductions of $\geq 3.5 \log _{10}$, and there were no significant differences (Fig. 3). A 1: 1,000 dilution of a $25 \mu \mathrm{g} / \mathrm{ml}$ QAC-2 solution with water was adequate for quenching its activity. There was no significant difference $(P=0.2372)$ in the number of bacterial colonies recovered between diluted QAC-2 $(25 \mathrm{ng} / \mathrm{ml})$ and water treatments.

Efficacy of two QAC formulations and sodium hypochlorite in disinfecting hard surfaces contaminated with $P$. savastanoi $\mathrm{pv}$. savastanoi in macerated olive tissue. QAC-1 and QAC-2 solutions at $2,000 \mu \mathrm{g} / \mathrm{ml}$ were highly and significantly $(P<0.0001)$ effective in disinfecting $P$. savastanoi pv. savastanoi-contaminated PVC piping in the presence of an organic load. After sanitizing contaminated PVC pipes with QAC-2 or QAC-1, 1.2 or $1.4 \log _{10}$ bacteria cells were recovered, respectively, with no significant difference between the two sanitizing formulations. In contrast, sodium hypochlorite was not effective in the presence of organic matter, with no significant difference in the number of bacterial colonies recovered as compared with the control (Fig. 4).

Performance of QAC-2 as a sanitizer for pruning equipment contaminated with $P$. savastanoi pv. savastanoi in field studies. Sanitation of a $P$. savastanoi pv. savastanoi-contaminated hedger with sodium hypochlorite $(50 \mu \mathrm{g} / \mathrm{ml})$ or QAC-2 effectively and significantly $(P \leq 0.0004)$ reduced the incidence of disease on 'Arbequina' and 'Manzanillo' olives in spring and fall studies as compared with not sanitizing the hedger before pruning a healthy olive tree (Fig. 5A to C). QAC-2 was significantly $(P \leq 0.0373)$ more effective than sodium hypochlorite in reducing knot formation on pruned trees in two of the four studies. Overall, reduction of knot formation from the control was 47.6 to $79.1 \%$ for sodium hypochlorite and 54.8 to $100 \%$ for QAC-2. When the hedger QAC-2 sanitation treatment was followed by a foliar application with copper or copper-kasugamycin, knot formation was sometimes further reduced as compared with the hedger sanitation alone. Additionally, copper and copper-kasugamycin applications were equally effective (Table 2). In these experiments, no disease was observed on pruning wounds created with a hedger that was not contaminated with the pathogen.

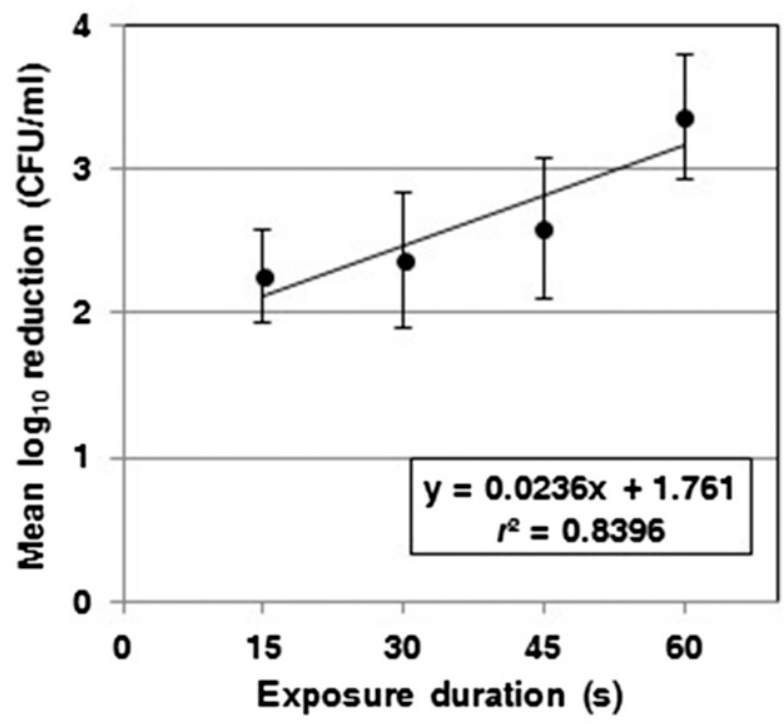

Fig. 2. Effect of exposure duration on toxicity of QAC-2 (a mixture of alkyl dimethylbenzyl, didecyl dimethyl, octyl decyl dimethyl, and dioctyl dimethyl ammonium chlorides) against Pseudomonas savastanoi pv. savastanoi in direct contact suspension assays. The mean number of bacterial colonies in the water controls was $5.27 \log _{10}$.
Efficacy of QAC-3 as a preinfection, protective treatment for olive injuries in field studies. Applications of copper hydroxide as a preinfection protective treatment to lateral and leaf scar wounds significantly reduced the incidence of knot formation on 'Arbequina' $(P<0.0001)$ and 'Manzanillo' $(P \leq 0.0152)$ olives as compared with the controls (Table 3). The incidence of knot formation in the controls was 70.0 to $92.5 \%$ on leaf scar wounds and 76.3 to $97.5 \%$ on lateral wounds, respectively, for the two cultivars. Copper hydroxide treatments reduced the incidence to 3.8 to $51 \%$ and 10.3 to $65 \%$, respectively, on leaf scar and lateral wounds. In contrast, treatments with QAC-3 were not effective and there was no significant difference in knot formation from the controls.

\section{Discussion}

In this study, we demonstrated for the first time that QACs are effective sanitizing agents for $P$. savastanoi pv. savastanoi-contaminated field

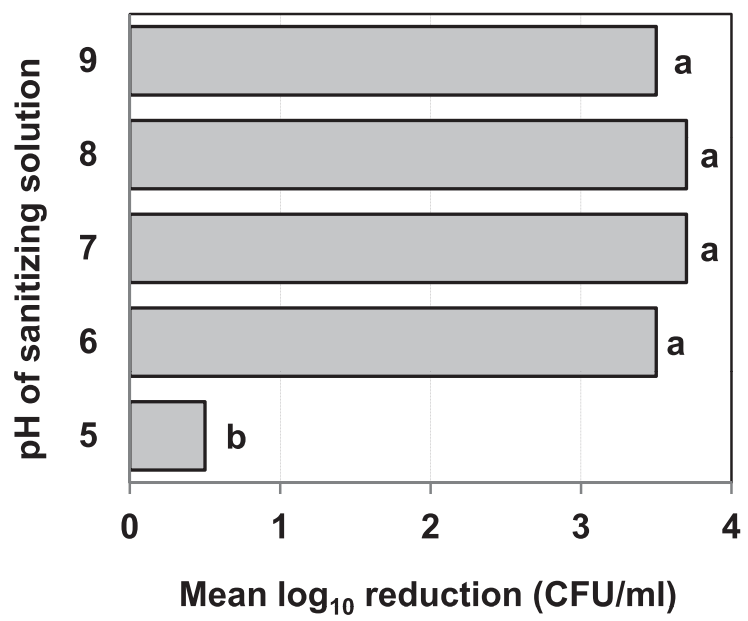

Fig. 3. Effect of $\mathrm{pH}$ on toxicity of QAC-2 (a mixture of alkyl dimethylbenzyl, didecyl dimethyl, octyl decyl dimethyl, and dioctyl dimethyl ammonium chlorides) against Pseudomonas savastanoi pv. savastanoi in direct contact suspension assays. Bacterial recovery was determined after exposure to $25 \mu \mathrm{g} / \mathrm{ml}$ QAC-2 for $60 \mathrm{~s}$ and expressed as mean $\log _{10}$ reduction. Horizontal bars with the same letters are not significantly different based on ANOVA and Fisher's LSD tests $(P \leq$ $0.05)$. Mean bacteria recovered from water controls were $4.65,5.07,5.21,5.17$, and $4.93 \log _{10} \mathrm{CFU} / \mathrm{ml}$, for $\mathrm{pH} 5,6,7,8$, and 9, respectively.

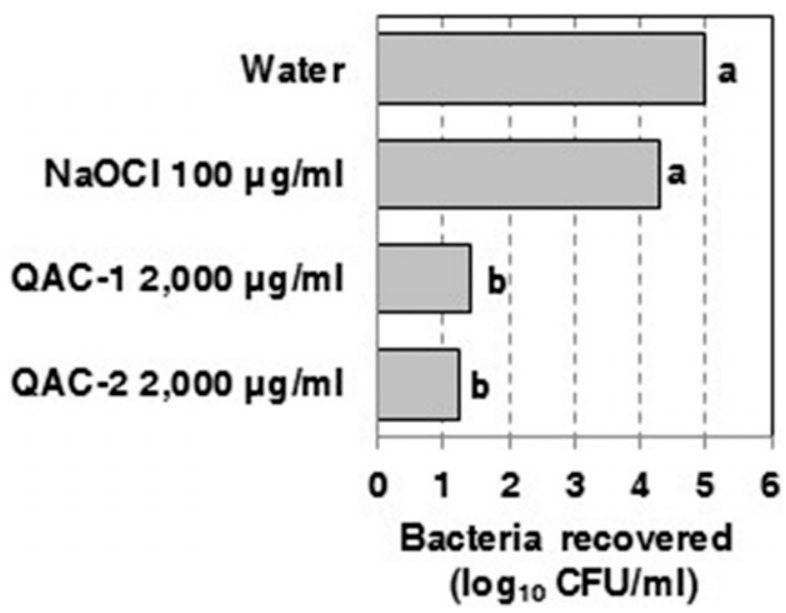

Fig. 4. Efficacy of QAC-1 (a mixture of n-alkyl dimethyl benzyl and n-alkyl dimethyl ethylbenzyl ammonium chlorides), QAC-2 (a mixture of alkyl dimethylbenzyl, didecyl dimethyl, octyl decyl dimethyl, and dioctyl dimethyl ammonium chlorides), and sodium hypochlorite in disinfecting polyvinyl chloride piping contaminated with Pseudomonas savastanoi pv. savastanoi in the presence of an organic load (macerated olive tissue). Horizontal bars with the same letters are not significantly different based on ANOVA and Fisher's LSD tests $(P \leq 0.05)$. $\mathrm{NaOCl}=$ sodium hypochlorite. 
equipment and that sanitation can be a viable management strategy to reduce pathogen dissemination in mechanized olive production. With a limited number of effective chemical treatments available and lack of olive knot-resistant cultivars, disease prevention remains an important aspect in successful olive cultivation (Penyalver et al. 2006). 'Arbequina' and 'Manzanillo' olives were used in our studies because they represent major oil and table cultivars planted in California, respectively. Based on our research, QAC-2 (i.e., Maquat 615-HD or Deccosan 321) was recently approved in California for field use on olive equipment at rates up to $2,000 \mu \mathrm{g} / \mathrm{ml}$ as a special local need (Section 24c) registration.

Several sanitizing agents showed high in vitro toxicity to $P$. savastanoi pv. savastanoi, but QAC-1 and QAC-2 were chosen for additional
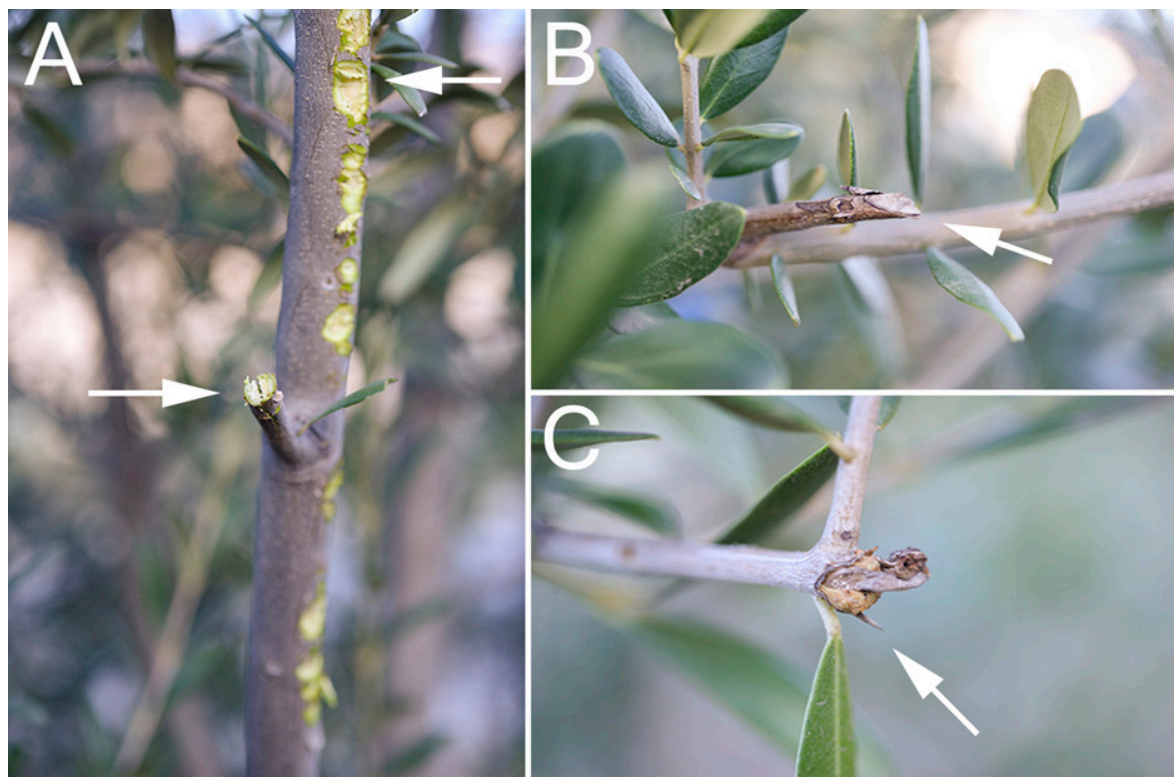

Fig. 5. Efficacy of a quaternary ammonium compound for decontamination of pruning equipment in a field trial. A, Hedger pruning wounds (arrows) on an 'Arbequina' olive branch. B, Terminal cut made with a hedger that was effectively sanitized and that healed without knot development (arrow). C, A terminal cut made using a contaminated hedger that resulted in knot development (arrow).

Table 2. Efficacy of sodium hypochlorite and a quaternary ammonia formulation (QAC-2) for sanitizing field equipment contaminated with Pseudomonas savastanoi pv. savastanoi before pruning 'Manzanillo' or 'Arbequina' olives in field trials

\begin{tabular}{|c|c|c|c|c|c|c|c|}
\hline \multirow{2}{*}{\multicolumn{2}{|c|}{ Sanitization treatment ${ }^{\mathrm{x}}$}} & \multirow{2}{*}{\multicolumn{2}{|c|}{ Foliar treatmenty }} & \multicolumn{4}{|c|}{ Reduction in knot incidence $(\%)^{\mathbf{z}}$} \\
\hline & & & & \multicolumn{2}{|c|}{ Manzanillo } & \multicolumn{2}{|c|}{ Arbequina } \\
\hline Sanitizer & Rate $(\mu \mathrm{g} / \mathrm{ml})$ & Bactericide & Rate $(\mu \mathrm{g} / \mathrm{ml})$ & Spring 2015 & Fall 2015 & Spring 2015 & Spring 2016 \\
\hline $\mathrm{NaOCl}$ & 50 & None & - & $79.1 \mathrm{~b}$ & $47.6 \mathrm{~b}$ & $71.4 \mathrm{~b}$ & $62.3 \mathrm{~b}$ \\
\hline QAC-2 & 2,000 & None & - & $100 \mathrm{a}$ & $54.8 \mathrm{~b}$ & $87.3 \mathrm{ab}$ & $90.6 \mathrm{a}$ \\
\hline QAC-2 & 2,000 & Copper hydroxide $(\mathrm{CH})$ & 4,200 & $100 \mathrm{a}$ & $90.5 \mathrm{a}$ & $95.2 \mathrm{a}$ & $96.2 \mathrm{a}$ \\
\hline QAC-2 & 2,000 & $\mathrm{CH}+$ kasugamycin & $4,200+100$ & $100 \mathrm{a}$ & $85.7 \mathrm{a}$ & $93.7 \mathrm{a}$ & $96.2 \mathrm{a}$ \\
\hline
\end{tabular}

${ }^{x}$ A gas-powered hedger was contaminated with P. savastanoi pv. savastanoi $\left(2 \times 10^{7} \mathrm{CFU} / \mathrm{ml}\right)$, sanitization treatments were applied to runoff, and after $90 \mathrm{~s}$, the hedger was used to prune healthy olive twigs and branches. $\mathrm{NaOCl}=$ sodium hypochlorite.

y Additional foliar sprays were applied using a back-pack sprayer at 933 liters/ha.

${ }^{\mathrm{z}}$ Evaluations were done after 7 to 9 months, and the number of knots that developed after sanitation on pruning wounds was enumerated and compared with that developing without sanitation. Values followed by the same letter are not significantly different in each column based on general linear model (GLM) and Fisher's LSD tests $(P \leq 0.05)$.

Table 3. Efficacy of a nonphenolic quaternary ammonium formulation and copper hydroxide in reducing knot development after field inoculation of leaf scar and lateral twig wounds of two olive cultivars

\begin{tabular}{|c|c|c|c|c|c|c|}
\hline \multirow[b]{3}{*}{ Cultivar } & \multirow[b]{3}{*}{ Treatmenty } & \multirow[b]{3}{*}{ Rate $(\mu \mathrm{g} / \mathrm{ml})$} & \multicolumn{4}{|c|}{ Incidence of knot formation $(\%)^{\mathrm{z}}$} \\
\hline & & & \multicolumn{2}{|c|}{2014} & \multicolumn{2}{|c|}{2015} \\
\hline & & & Leaf scars & $\overline{\text { Lateral wounds }}$ & Leaf scars & $\overline{\text { Lateral wounds }}$ \\
\hline \multirow{3}{*}{ Arbequina } & Water control & - & $92.5 \mathrm{a}$ & $97.5 \mathrm{a}$ & $85.0 \mathrm{a}$ & $95.0 \mathrm{a}$ \\
\hline & QAC-3 & 222 & $90.0 \mathrm{a}$ & $97.5 \mathrm{a}$ & $97.5 \mathrm{a}$ & $100.0 \mathrm{a}$ \\
\hline & Copper hydroxide & 4,200 & $3.8 \mathrm{~b}$ & $10.3 \mathrm{~b}$ & $30.0 \mathrm{~b}$ & $52.5 \mathrm{~b}$ \\
\hline \multirow[t]{3}{*}{ Manzanillo } & Water control & - & $71.3 \mathrm{a}$ & $76.3 \mathrm{a}$ & $77.8 \mathrm{ab}$ & $96.0 \mathrm{a}$ \\
\hline & QAC-3 & 222 & $71.3 \mathrm{a}$ & $79.1 \mathrm{a}$ & $83.0 \mathrm{a}$ & $100.0 \mathrm{a}$ \\
\hline & Copper hydroxide & 4,200 & $8.0 \mathrm{~b}$ & $13.3 \mathrm{~b}$ & $51.0 \mathrm{~b}$ & $65.0 \mathrm{~b}$ \\
\hline
\end{tabular}

${ }^{\mathrm{y}}$ Spray treatments with QAC-3 (didecyl dimethyl ammonium chloride) were applied to leaf scar and lateral twig wounds in October 2014 or April 2015 using a hand-held sprayer. After air-drying, wounds were spray-inoculated with Pseudomonas savastanoi pv. savastanoi $\left(2 \times 10^{8} \mathrm{CFU} / \mathrm{ml}\right)$.

${ }^{\mathrm{z}}$ Knot formation was evaluated after 7 to 9 months, and incidence was based on the number of wounds with knots of the total number of wounds inoculated. Incidence values followed by the same letter for each cultivar in each column are not significantly different based on general linear model (GLM) and Fisher's LSD tests $(P \leq 0.05)$. 
laboratory and field studies because agricultural formulations and labels currently exist for other crops such as citrus (Schubert and Sun 2003) that potentially could be registered for use on olives. In direct exposure laboratory assays, sodium hypochlorite was also highly effective. The sanitizers were compared at equivalent active ingredient concentrations (i.e., $5 \mathrm{mg}$ /liter), but the dilution method for quenching in the assay that was adequate for four sanitizers, did not completely eliminate the biocidal activity of sodium hypochlorite. This could have resulted in a slightly overestimated activity of sodium hypochlorite because the test suspension was plated approximately $30 \mathrm{~min}$ after the dilution. Although sodium hypochlorite is very effective and of low cost, there are several disadvantages with this sanitizer. Sodium hypochlorite is highly corrosive and would cause unacceptable damage to expensive olive harvesting and pruning equipment. Furthermore, its activity is compromised in the presence of organic material and alkaline environments, and is generally applied at low rates (i.e., 50 to $100 \mu \mathrm{g} / \mathrm{ml}$ ) when nonlabeled bleach formulations are employed. Currently, there are no other labels of sodium hypochlorite that allow high rates on field equipment. An additional benefit of QACs is that treated surfaces only need to be air-dried in contrast to many other sanitizers that require rinsing.

Previous research by others indicated that $P$. savastanoi pv. savastanoi can be disseminated by pruning tools that were contaminated by bacterial suspensions (Wilson 1935). Our research further confirmed this mechanism of disease spread to healthy trees using naturally produced inoculum from olive knots. Additionally, we demonstrated that the pathogen can be spread by tools in the absence of externally applied wetness. Still, wetness applied to knots or cutting tools resulted in a significant increase in knot development, stressing the importance of pruning olives only during dry periods.

In our studies, QAC-2 remained effective over a $\mathrm{pH}$ range from 6 to 9 , a valuable property when considering that the $\mathrm{pH}$ of water sources used for preparing tank mixes in the field can differ by location, and ground water in the main agricultural areas of California is commonly alkaline.

In hard surface, laboratory disinfectant assays, two QAC formulations were challenged against $P$. savastanoi pv. savastanoi under conditions that simulated the environment encountered during harvest. Both formulations reduced the number of viable bacteria recovered from the contaminated PVC piping to low levels, although higher concentrations of the sanitizers and longer exposures had to be used in this assay as compared with direct exposure assays. Sodium hypochlorite at $100 \mu \mathrm{g} / \mathrm{ml}$ was not efficacious in the presence of high amounts of organic material. PVC piping was utilized as a hard surface in this assay because automated harvesters commonly use this material as 'beater bars' to remove fruit from trees. These surfaces need to be quickly and effectively disinfected to accomplish orchard practices in a timely manner, and this can be achieved by QAC sanitation.

To evaluate QAC efficacy against olive knot under field conditions, a gas-powered hedger was used to prune 'Arbequina' and 'Manzanillo' olive trees. QAC-2 rates and exposure durations were based on in vitro results and the registrant's recommendations. Sodium hypochlorite was included for comparison at a typical usage rate of $50 \mu \mathrm{g} / \mathrm{ml}$. The sanitizers displayed good activity even when the hedger was contaminated with a high inoculum concentration $\left(2 \times 10^{7} \mathrm{CFU} / \mathrm{ml}\right)$. Sanitation with sodium hypochlorite was effective in this experiment, with a minimum amount of contamination with organic material based on the sequence of contamination, treating, and hedging. QAC-2 treatments, however, performed significantly better in most studies (Table 2). Cutting wounds made with a QAC-2-sanitized hedger that were treated with copper hydroxide or copper hydroxide-kasugamycin mixtures 1 to $2 \mathrm{~h}$ afterward further improved control. These results indicate that applications of a sanitation treatment in combination with a foliar spray treatment can help prevent a majority of infections from occurring.

This study also examined the possibility of using a QAC (e.g., QAC-3) as a protective treatment on olive wounds. The nonphenolic QAC formulation was chosen because it is labeled for use on ornamental crops as a pesticide and disinfectant. The QAC-3 treatment proved to be ineffective against $P$. savastanoi pv. savastanoi when used to treat two types of wounds on two olive cultivars before inoculation. Field rates were used at the maximum label, and higher rates were not tested due to concerns of phytotoxicity. In contrast, a standard treatment of copper hydroxide was effective to highly effective in these studies.

In summary, the newly registered QAC-2 was a highly effective sanitizer of hard surfaces and orchard equipment in the presence of organic matter in laboratory and field studies. Sanitation practices are an important component of olive knot disease management (Quesada et al. 2010b; Teviotdale and Krueger 2004). Growers currently treat olives with a foliar application of copper after harvest and pruning as a standard practice. Integration of copper sprays with an equipment sanitation treatment will further improve disease prevention.

\section{Acknowledgments}

We thank E. Fichtner, D. Lightle, and W. Krueger (University of California Cooperative Extension, Tulare, Butte/Glenn, and Glenn Co., respectively) for collecting diseased olive samples. This work was supported by AgAdvisors Inc., Yuba City, $\mathrm{CA}$, and funded by the California Olive Board and the California Olive Oil Council.

\section{Literature Cited}

Bioletti, F. T. 1898. The olive knot. Calif. Agric. Exp. Stn. Bull. 120.

Bock, C. H., Parker, P. E., Cook, A. Z., Graham, J. H., and Gottwald, T. R. 2011. Infection and decontamination of citrus canker-inoculated leaf surfaces. Crop Prot. 30:259-264.

Ferguson, L., Rosa, U. A., Castro-Garcia, S., Lee, S. M., Guinard, J. X., Burns, J. Krueger, W. H., O'Connell, N. V., and Glozer, K. 2010. Mechanical harvesting of California table and oil olives. Adv. Hortic. Sci. 24:53-63.

Gardan, L., Bollet, C., Abu Ghorrah, M., Grimont, F., and Grimont, P. A. D. 1992 DNA relatedness among the pathovar strains of Pseudomonas syringae subsp. savastanoi Janse (1982) and proposal of Pseudomonas savastanoi sp. nov. Int. J. Syst. Bacteriol. 42:606-612.

Gilbert, P., and Moore, L. E. 2005. Cationic antiseptics: diversity of action under a common epithet. J. Appl. Microbiol. 99:703-15.

Horne, T., Parker, B., and Daines, L. L. 1912. The method of spreading of the olive knot disease. Phytopathology 2:101-105.

Iacobellis, N. S. 2001. Olive knot. Pages 713-715 in: Encyclopedia of Plant Pathology. Vol. 2. O. C. Maloy and T. D. Murray, eds. John Wiley and Sons, Inc., New York.

King, E. O., Ward, M. K., and Raney, D. E. 1954. Two simple media for the demonstration of pyocyanin and fluorescein. J. Lab. Clin. Med. 44:301-307.

Lucas, G. B. 1955. The cardinal temperatures and $\mathrm{pH}$ response of Thielaviopsis basicola. Mycologia 47:793-798.

Penyalver, R., Garcia, A., Ferrer, A., Bertolini, E., and Lopez, M. M. 2000 Detection of $P$. savastanoi pv. savastanoi in olive plants by enrichment and PCR. Appl. Environ. Microbiol. 66:2673-2677.

Penyalver, R., García, A., Ferrer, A., Bertolini, E., Quesada, J. M., Salcedo, C. I., Piquer, J., Pérez-Panadés, J., Carbonell, E. A., del Río, C., Caballero, J. M., and López, M. M. 2006. Factors affecting Pseudomonas savastanoi pv. savastanoi plant inoculations and their use for evaluation of olive cultivar susceptibility. Phytopathology 96:313-319.

Quesada, J. M., Penyalver, R., Pérez-Panadés, J., Salcedo, C. I., Carbonell, E. A., and López, M. M. 2010a. Dissemination of Pseudomonas savastanoi pv. savastanoi populations and subsequent appearance of olive knot disease. Plant Pathol. 59:262-269.

Quesada, J. M., Penyalver, R., Pérez-Panadés, J., Salcedo, C. I., Carbonell, E. A., and López, M. M. 2010b. Comparison of chemical treatments for reducing epiphytic Pseudomonas savastanoi pv. savastanoi populations and for improving subsequent control of olive knot disease. Crop Prot. 29:1413-1420.

Rahn, O., and Van Eseltine, W. P. 1947. Quaternary ammonium compounds. Annu. Rev. Microbiol. 1:173-192.

Ramos, C., Matas, I. M., Bardaji, L., Aragon, I. M., and Murillo, J. 2012. Pseudomonas savastanoi pv. savastanoi: some like it knot. Mol. Plant Pathol. 13:998-1009.

Schroth, M. N., and Hildebrand, D. C. 1968. A chemotherapeutic treatment for selectively eradicating crown gall and olive knot neoplasms. Phytopathology 58:848-854.

Schroth, M. N., Hildebrand, D. C., and O'Reilly, H. J. 1963. Off-flavor of olives from trees with olive knot tumors. Phytopathology 58:524-525.

Schroth, M. N., Osgood, J. W., and Miller, T. D. 1973. Quantitative assessment of the effect of the olive knot disease on olive yield and quality. Phytopathology 63:1064-1065.

Schubert, T. S., and Sun, X. 2003. Bacterial citrus canker. Plant Pathology Circular No. 377 Fl. Dept. of Agriculture \& Cons. Svcs. Division of Plant Industry, Gainesville, FL.

Sibbett, G. S., and Ferguson, L. 2005. Olive Production Manual. 2nd ed. University of California Agriculture and Natural Resources, publication no. 3353.

Teviotdale, B. L., and Krueger, W. H. 2004. Effects of timing of copper sprays, defoliation, rainfall, and inoculum concentration on incidence of olive knot disease. Plant Dis. 88:131-135.

Tous, J., Romero, A., and Hermoso, J. F. 2010. New trends in olive orchard design for continuous mechanical harvesting. Adv. Hortic. Sci. 24:43-52.

Vossen, P. 2007. Olive oil: history, production, and characteristics of the world's classic oils. HortScience 42:1093-1100.

Walker, H. W., and LaGrange, W. S. 1991. Sanitation in food manufacturing operations. Pages 791-801 in: Disinfection, Sterilization, and Preservation. S. B. Seymour, ed. Lea \& Febiger, London.

Wilson, E. E. 1935. The olive knot disease: Its inception, development and control. Hilgardia 9:231-264.

Young, J. M. 2004. Olive knot and its pathogens. Australas. Plant Pathol. 33:33-39. 